\title{
Inhibition activity of Robusta coffee beans polyphenol extract on the production of TNF-a neutrophil cells
}

\author{
Tantin Ermawati, Zahara Meilawaty, Happy Harmono \\ Department of Biomedical, Faculty of Dentistry, Universitas Jember, Jember, East Java, Indonesia \\ Jl Kalimantan No 37, Jember, East Java, Indonesia; e-mail: tantin.ermawati@unej.ac.id
}

Submitted: $23^{\text {rd }}$ October 2017; Revised: 29 ${ }^{\text {th }}$ January 2018; Accepted: $22^{\text {nd }}$ May 2018

\begin{abstract}
Polyphenols are one of the active substances in the Robusta coffee beans with various benefits for humans' health including anti-inflammation. neutrophil cell (polymorphonuclear PMN) plays a significant role as the primary immune response against foreign agent. Inflammatory response is characterized by the production of pro-inflammatory cytokines such as tumor necrosis factor- $\alpha$ (TNF- $\alpha$ ). Hence, the purpose of this study is to determine anti-inflammation capacity of Robusta coffee beans polyphenols extract on the TNF- $\alpha$ production in neutrophil cells. Neutrophil was derived from human peripheral venous blood by means of gradient density method. One hundred microliter of neutrophil $\left(1,5 \times 10^{3}\right.$ cell) was incubated with $3.13 \%, 6.25 \%, 12.5 \%, 25 \%$ polyphenol extract and exposed with $100 \mu \mathrm{l}$ of Lipopolysaccharides (LPS) $25 \mathrm{mg} / \mathrm{ml}$. The production of TNF- $\alpha$ were determined by ELISA. Data were analyzed by one way Anova. Polyphenols of Robusta coffee bean extract was shown to inhibit TNF- $\alpha$ production in LPS-exposed neutrophil cells compared to controls. Whereas, LPS-exposed neutrophil increased TNF- $\alpha$ production. The most effective concentration to inhibit TNF- $\alpha$ production was $12.5 \%$. It was concluded that polyphenols of Robusta coffee beans has anti-inflammatory properties as indicated by its ability to decrease TNF- $\alpha$ levels.
\end{abstract}

Keywords: LPS; neutrophil; polyphenol; Robusta coffee beans; TNF- $\alpha$

\section{INTRODUCTION}

As a widely cultivated plantation crop in Indonesia, coffee is generally consumed as a beverage. However, countless researches today have started to address the benefit of coffee for human health. One of the widely cultivated coffee beans, Robusta coffee is extensively developed because it is easier to grow in any climate than other types of coffee beans. ${ }^{1}$ Several studies have shown that coffee has some beneficial substances for health, one of which is a polyphenol compound which has an extract content of $8.1 \mu \mathrm{g} / \mathrm{g}$ in 250 grams of coffee beans.Polyphenols are natural compounds often found in natural plants such as coffee beans, tea and fruits. A cup of coffee normally contains $100 \mathrm{mg}$ of polyphenols. Polyphenols are compounds with various potential properties such as anti-inflammatory, antioxidant, and anticancer. ${ }^{2}$ Several laboratory studies show that polyphenols' property as antioxidants play a significant role against free radical molecules and prevent oxidative stress. ${ }^{3}$ Polyphenols are believed to prevent disease through various mechanisms of potential enzyme inhibition of bacterial replication, apoptosis induction in tumor cells, and stimulation of monocytes/macrophages to produce cytokines in neutrophil cells. ${ }^{4}$

Neutrophils are non-specific immune cells that take part in the body's protective mechanism which serves as the key immune response to a lesion. Active neutrophils in the inflammatory process are responsible for tissue damage towards the lesion area by releasing inflammatory mediators. ${ }^{5}$ Each day, a number of $10^{11}$ neutrophils circulate in the blood which acts as a immunity against exposure to foreign microorganisms. Neutrophils can migrate from vascular tissue by themselves or in response to chemical elements (chemo taxis). ${ }^{6}$ As phagocytic cells, neutrophils can respond to microorganisms or soluble stimuli such as LPS bacterial. 
Lipopolysaccharide is endotoxin since it induces the production of local factors, namely pro-inflammatory cytokines such as interleukin (IL) $-1 \alpha, I L-1 \beta$, tumor necrosis factor- $\alpha$ (TNF- $\alpha$ ), and prostaglandin 2 (PGE2). ${ }^{7,8}$ During an inflammatory condition caused by an injury, neutrophils play an active role in responding against foreign substances and produce several cytokines including TNF- $\alpha$. TNF- $\alpha$ which can be produced by several cells such as macrophages, monocytes, neutrophils, smooth muscle cells and mast cells. ${ }^{9}$ On this basis, this study aims to determine the anti-inflammatory potential of Robusta coffee bean polyphenols extract on TNF- $\alpha$ production in neutrophil cells.

\section{MATERIALS AND METHODS}

The study was designed as an in-vitro experiment to determine the anti-inflammatory potential of Robusta coffee bean polyphenol extract against TNF- $\alpha$ production in neutrophil cells. The study was approved by the ethics commission of the Faculty of Dentistry, Universitas Gadjah Mada No. 001212/ KKEP/FKG-UGM/EC/2017. It was conducted at the Bioscience Laboratory of RSGM of The University of Jember, Chemical Engineering Laboratory of Malang POLINEMA, Anatomical Pathology Laboratory, and Microbiology Laboratory, Faculty of Dentistry, The University of Jember.

The test materials used in this study were polyphenol extract of Robusta Coffee beans obtained from the plantation of PTPN XII Jember. The making of coffee bean polyphenol extract was carried out by sonification method in the chemical engineering laboratory of Malang (POLINEMA). First, Robusta coffee beans were weighed to determine its initial weight. Afterwards, the coffee beans were mashed into fine powder using a hammer mill tool to reduce its particles to a size of \pm 40 mesh. The fine powder of coffee beans was then put into a beaker and was added with ethanol $96 \%$ with a ratio of $1: 5$. In the following stage, the sonification process was carried out for 1 hour with a frequency of $80 \mathrm{kHz}$, and it was repeated three times to obtain high polyphenol extract. The process resulted Robusta coffee polyphenol extract in the form of paste. Paste of Robusta polyphenol extract was diluted using a dilution formula with a concentration of $3.13 \%, 6.25 \%, 12.5 \%$, and $25 \%$.

Neutrophil isolates were obtained by the gradient density technique using histopaque 1199 and lymphoprep. First, blood $6 \mathrm{ml}$ taken through the peripheral vein (vein cubiti) of the respondent was collected in the heparin tube. Then, istopaque $3 \mathrm{ml}$ was coated on the Falcon tube, and $3 \mathrm{ml}$ of Lymphoprep was superimposed over the Histopaque 1119 layer. Afterwards, blood $6 \mathrm{ml}$ was carefully coated on the Falcon tube above the Histopaque of 1119 layers and Lymphoprep. Then, it was centrifuged at $900 \mathrm{G}$ for 30 minutes at $25^{\circ} \mathrm{C}$. The results formed 6 layers, namely plasma layers, mononuclear blood cells, Lymphoprep, granulocytes (neutrophils), Histopaque 1119, and erythrocytes. The granulocyte layer (neutrophils) was taken and added with $1000 \mu \mathrm{l}$ of HBSS. It was centrifuged at $700 \mathrm{G}$ for 10 minutes at $37^{\circ} \mathrm{C}$. After that, supernatant (top layer) was removed and added with $1500 \mu \mathrm{l} \mathrm{HBSS}$ to the granulocyte layer (neutrophils). Cell population was observed with an inverted microscope 400 magnification. Viability Neutrophil was isolated using Trypan blue with 1: 2 dilution. The number of living cells was calculated using a large field of view / 100 cells which was repeated for 3 times. Neutrophils were said to be alive if the percentage of cell viability was between $90-95 \%$. Then, the resulted neutrophil isolates were ready for testing.

LPS (Echericia coli 0111: B4) (List Biology Laboratory, Campbel, CA, USA) was used as chemical inflammatory inducer. LPS $100 \mu \mathrm{l} /$ well was diluted using sterile distilled water with a ratio of 1: 2. Futhermore LPS was exposed to neutrophil cells as inducers of inflammation to be tested later.

One hundred microliter of neutrophil $\left(1,5 \times 10^{3}\right.$ cells $)$ was inoculated in each well culture. Neutrophil was incubated with various concentration of Robusta coffee polyphenol extract $(3.13 \%, 6.25 \%, 12.5 \%, 25 \%)$. The negative control groups were LPS-exposed neutrophil and a group containing neutrophil isolates in the RPMI medium. Neutrophil was exposed with LPS for 3 times. The used polyphenol and LPS extract amounted to 100 $\mu \mathrm{l} / \mathrm{wel}$. Incubation of polyphenol and LPS extracts 
on neutrophil cells was carried out for 2 hours. Sample preparation was carried out by centrifuging 2000-3000 rpm for 15 minutes to obtain supernatant.

Supernatant $40 \mu \mathrm{l}$ was added in the ELISA kit well (Bioassay Technology Laboratory, Shanghai, China), and then it was added with 10 $\mu l$ of biotin-conjugate anti-human antibody and was homogenized. Each well sample was filled with 50 $\mu \mathrm{l}$ of streptavidin HRP and incubated for 1 hour at 37 ${ }^{\circ} \mathrm{C}$. The sample was washed and was added with $50 \mu \mathrm{l}$ of substrate solution $\mathrm{A}$ and substrate solution $B$. The next step was incubation for 10 minutes at $37^{\circ} \mathrm{C}$, after which $50 \mu \mathrm{l}$ of stop solution was added, turning the color from blue to yellow. Samples were then read using an ELISA (ELISA reader) device with a wavelength of $450 \mathrm{~nm}$.

Data on TNF- $\alpha$ production were analyzed using ANOVA (SPSS). Its normality was tested with the Kolmogorov Smirnov test and its homogeneity was tested with the Levene test. The test results show that data were normally distributed and homogeneous as shown by the value of $p>0.05$. Afterwards, the researcher carried out the one way ANOVA parametric statistical test.

\section{RESULTS}

This study used neutrophil obtained from peripheral blood of healthy people who had been stained with Giemsa. The results of neutrophil isolates are presented in the following figure. The calculation of TNF- $\alpha$ production on neutrophil cells using the Elisa method is shown in Table 1.

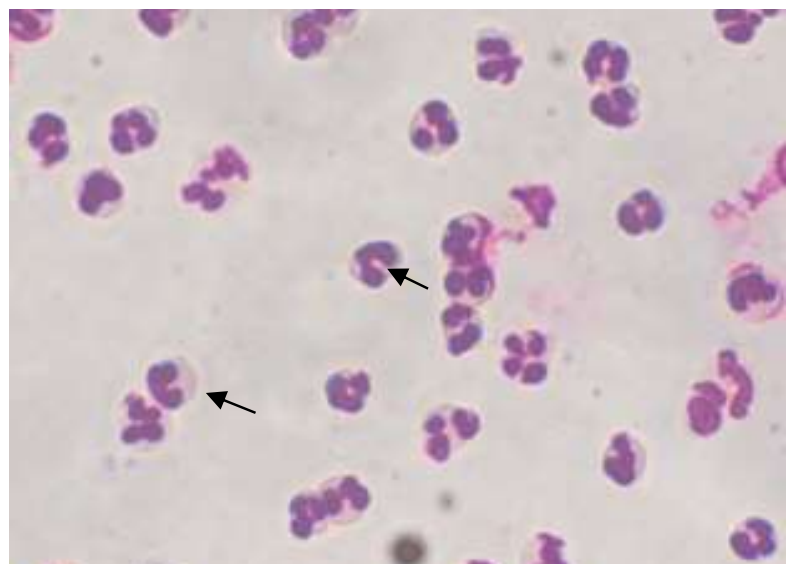

Figure 1. Using Giemsa staining with 1000x enlargement, it is apparent that neutrophil with purplish blue color is the polymorphonuclear nucleus
Table 1. Average and standard deviation (SD) of TNF- $\alpha$ production between the treatment and control groups

\begin{tabular}{ccc}
\hline \multicolumn{3}{c}{ Production of TNF- $\alpha(\mathrm{ng} / \mathrm{L})$} \\
\hline No. & Treatment Group & $\mathrm{X} \pm \mathrm{SD}$ \\
\hline 1 & Group 1 & $313.95 \pm 23.11$ \\
2 & Group 2 & $361.38 \pm 66.11$ \\
3 & Group 3 & $340.93 \pm 26.34$ \\
4 & Group 4 & $327.87 \pm 50.39$ \\
5 & Group 5 & $310.93 \pm 6.77$ \\
6 & Group 6 & $303.67 \pm 16.09$ \\
\hline
\end{tabular}

Group 1: Neutrophils in RPMI media

Group 2: Neutrophils exposed to LPS (negative control)

Group 3: Neutrophils incubated with polyphenol extract $3.13 \%$ and exposed to LPS

Group 4: Neutrophils incubated with $6.25 \%$ polyphenol extract and exposed to LPS

Group 5: Neutrophils incubated with $12.5 \%$ polyphenol extract and exposed to LPS

Group 6: Neutrophils incubated with 25\% polyphenol extract and exposed to LPS

Table 1 shows that there was an increase in TNF- $\alpha$ production of the neutrophil control group exposed to LPS (361.38 \pm 66.11$)$ as compared to group 1 of neutrophils without exposure to LPS. The data were analyzed using the one way ANOVA analysis and resulted in $p>0.005$. This indicates no significant differences between treatment groups.

\section{DISCUSSION}

Polyphenols have been widely studied because they have various benefits for health as well as for pharmacological therapy. Epidemiological studies show that polyphenols can significantly contribute in treating several chronic diseases such as cardiovascular disease, cancer, diabetes mellitus, infection, aging and asthma. Some studies report that polyphenols can act as anti-inflammatory agents. The mechanism of polyphenols as antiinflammatory has been widely reported, but the beneficial effects of polyphenols on neutrophil cells have not been discussed in depth. ${ }^{10,11}$

Inflammation is a natural mechanism carried out by the body in counteracting foreign pathogens associated with several diseases such as bacterial infections, viruses, allergens, toxic chemicals and chronic diseases. Neutrophil plays a key part in the forefront immune response against diseases. Neutrophil cells in the blood will become active when exposed to bacteria, bacterial products (LPS) or viruses. These cells in the blood work 
through 2 processes. First, passive neutrophils will become active when induced by bacterial products (LPS) and cytokines or chemokines, TNF- $\alpha$, GMCSF (granulocyte-macrophage colony-stimulating factors), IL-8 and IF-X. Second, the active neutrophils will go to an inflammatory area that will activate a signal to kill bacteria. ${ }^{12,13}$

LPS can induce neutrophils to release TNF- $\alpha$ and trigger an inflammatory response. The role of TNF- $\alpha$ in the process of apoptosis is mediated by reactive oxygen species (ROS). Neutrophils initially respond LPS stimuli with a respiratory burst by activating the enzyme system of NADPH oxidase on the neutrophil membrane and triggering a respiratory burst (increased cellular oxygen consumption). The reaction between oxygen and NADPH oxidase produces superoxide radicals. ${ }^{14}$ This will soon be followed by the formation of other oxidants (hydrogen peroxides, superoxide anions, hydroxyl radicals) in large quantities, resulting in oxidative burst. The above ROS products can be harmful to aerobic metabolism which causes DNA mutations, lipid peroxidation and protein oxidation. ${ }^{15,16}$ Mitochondria are the target source of ROS. The excess production of ROS will induce depolarization of MMP (mitochondrial membrane potential) and release of cyt which triggers caspase activation. The formation of ROS causes DNA damage which further promotes apoptosis. ${ }^{17}$

Data revealed that the neutrophil cell treatment group that had been incubated with polyphenols tended to decrease the production of TNF- $\alpha$ close to normal (negative control), but after one way ANOVA statistical analysis, there were no significant differences found between treatment groups. This is probably due to different chemical structures of polyphenol extracts, leading to insignificant differences between groups. This result is supported by $\mathrm{Ciz}$ et al. showing that flavonoid resistance to respiratory burst in phagocytic cells is mediated by various mechanisms. The flavonoid effect on neutrophil cells in mammals is very complex because it is influenced by the inflammatory location, polyphenol structure, distribution of subcellular flavonoids and stimulation of inflammation. ${ }^{18}$ Thus, it is recommended that future study conduct phytochemical test of polyphenol extract to classify some polyphenols such as flavonoid phenolic acids, stylbene, tannins and lignans. ${ }^{19}$

The concentration approaching the normal value is $12.5 \%$, while the $25 \%$ concentration of TNF- $\alpha$ production is said to be lower than normal. This decrease in TNF- $\alpha$ production shows that polyphenols can act as anti-inflammatory agent through the mechanism of neutrophil cells. Based on the research, it is conclusive that polyphenols have the ability to protect neutrophil cells. Robusta coffee bean polyphenols work by binding ROS to produce a chain reaction to maintain cell viability. 20 Polyphenols can reduce the activity of catalytic enzymes in ROS and protect cells from damaging oxidative action. Fraga et al stated that polyphenols can affect cell function by changing the structure of plasma membranes and physical characteristics such as viscosity and electrical properties. This effect can be seen when polyphenols are absorbed in the membrane to form physical barriers or hydro soluble radicals. In addition, when entering the bilayer layer the polyphenols, they can dissolve fat-soluble radicals. ${ }^{21}$

Other studies suggest that polyphenols can react to the plasma membrane in the presence of non-polar components in the hydrophobic membrane layer. In this way, changes in the membrane affect the amount of fat and protein oxidation. ROS is known to produce free metal ions derived from the release of hydrogen peroxide by the formation of highly reactive hydroxyl radicals. The low redox potential of polyphenols by thermodynamics can reduce free radicals which are highly oxidizing by binding to metal ions such as iron and copper. In addition, Drabikova et al articulated that polyphenols can also be immunomodulatory and antioxidant in nature against exposure to an agent. $^{19,22,10}$

\section{CONCLUSION}

The study reveals that the polyphenols of Robusta coffee beans can act as anti-inflammatory agent by counteracting free radicals due to exposure to bacterial products by decreasing the production 
of TNF- $\alpha$. The concentration of polyphenol extract of $12.5 \%$ is known to be the most effective concentration of polyphenol. It is expected that this research will be referred in the use of coffee beans as a topical anti-inflammatory drug in the oral cavity.

\section{ACKNOWLEDGEMENT}

The researcher would like to exert gratitude to the Directorate of Research and Community Service (DPRM) and The Directorate General of Research and Development, Ministry of Research, Technology and Higher Education 2016 which have provided us with the research grant for the research implementation.

\section{REFERENCES}

1. Prajitiasari ED. Analisis critical value factors industri kopi biji rakyat di Kabupaten Jember. [Internet]. Universitas Jember: 2013 [cited 2018 October 20]. Available: http://repository.unej. ac.id/handle/123456789/58797?show=full

2. Pandey KB, Rizvi SI. Plant polyphenols as dietary antioxidants in human health and disease. Oxidative Medicine and Cellular Longevity. 2009; 2(5): 270-278.

3. Hii CL, Law CL, Suzannah S, Misnawi, Cloke M. Polyphenols in cocoa (Theobroma cacao L). J Food Ag-Ind. 2009; 2(4); 702-722.

4. Ferrazzano GF, Amato I, Ingenito A, Zarrelli, Pinto G, Pollio A. Plant polyphenols and their anti-cariogenic properties: A Review Molecules. 2011; 16: 1486-1507.

5. Houghton AM. Matrix metalloproteinases in destructive lung disease. Matrix Biol. 2015; 44: 167-174.

6. Newman MG, Takey HH, Klokkevold PR, Carranza FA. Carranza's Clinical Periodontology $12^{\text {th }}$ ed. St Missouri: Elsevier Saunders; 2015. 92-100.

7. Chen D, Nie M, Fan M, Bian Z. Anti-inflamatory activity of curcumin in macrophages stimulated by lipopolysaccharides from porphyromonas gingivalis. Pharmacology. 2008; 82: 264-269.

8. Indahyani DE, Santoso AS, Utoro T, Marsetyawan HNE. Pengaruh induksi lipopolisakarida (LPS) terhadap osteopontin tulang alveolaris tikus pada masa erupsi gigi.
Ind.J.Dent. 2007; 14: 2-7.

9. Driscoll KE, Carter JM, Hassenbein DG, Howard B. Cytokines and particle-induced inflammatory cell recruitment. Environment Health Perspective. 2007; 105(5).

10. Drabikova K, Perecko T, Nosal R, Harmatha J, Smidrkal J, Jancinova V. Polyphenol derivatepotential regulators of neutrophil activity. Interdisciplinary Toxicology. 201; 5: 65-70.

11. Pandey BK, Rizvi SI. Plant polyphenols as dietary antioxidant in human health and disease. Oxidative Medicine and Cellular Longevity. 2009; 2: 270-278.

12. Berlett BS, Stadtman ER. Protein oxidation in aging disease, and oxidative stress. Journal of Biological Chemistry. 2007; 272: 20313-20316.

13. Wright HL, Moots RJ, Bucknall RC, Edwards SW. Neutrophil function in inflammation and inflammatory disease. Rhematology. 2010; 49: 1618-1631.

14. Robinson JM. Reactive Oxygen species in phagocytic leukocytes. Histochem Cell Biol. 2008; 281-297.

15. Birben E, Sahiner UM, Sackesen C, Erzurum $S$, Kalayci O. Oxidative stress and antioxidant defense. Word Allergy Organization Journal. 2012; 5: 9-19.

16. Lambeth JD, Krause KH, Clark RA. NOX enzymes as novel targets for drug development. Semin Immunopathol. 2008; 30(3): 339-363.

17. Guo H, Chen L, Cui H, Peng X, Fang J, Zuo Z, Deng J, Wang $X$, Wu B. Research advance on pathway of nickel-induced apoptosis. Int J.Mol Sci. 2016; 17(10): 1-18.

18. Ciz M, Denev P, Kratchanova M, Vasicek $O$, Ambrozova G, Lojek A. Flavonoids inhibit the respiratory burst of neutrophils in mammals. Oxidative Medicine and Cellular Longevity. 2012; 1-7.

19. Mocanu MM, Nagy P, Szöll"osi J. Chemoprevention of breast cancer by dietary polyphenols. Molecules; 2015: 22578-22620.

20. Kumar S, Pandey AK. Chemistry and biological activities of flavonoid: in overview "The scientific World Journal. 2013; 1-6. 
21. Fraga CG, Galleano M, Verstraten S, Oteiza $\mathrm{PI}$. Basic biochemical mechanism behind the health benefits of polyphenol. Mol Asp Med. 2010; 31: 435-445.
22. Hussain T, Tan B, Yin Y, Blachier F, Tossou MCB, Rahu N. Review article: Oxidative stress and inflammation: what polyphenols can do for us. Oxidative Medicine and Cellular Longevity. 2016; 9: 1-9. 